ARTICLE

\title{
Internationalization of Higher Education Institutions: perceptions of scholars
}

\author{
Rejane Pinto Costa ${ }^{a}$ \\ Alberto Gabbay Canen ${ }^{b}$
}

\section{Abstract}

This study aims to contribute to Brazilian Higher Education Institutions (HEIs) within an international perspective. Our main argument is that when HEIs value international research and students'/academics' international mobility, such institutions contribute to enlarge the view of internationalization throughout Brazil and push HEIs far beyond political, economic and commercialization processes considered to be, today, key drivers for Higher Education changes in terms of internationalization. To achieve this aim, the most recent tendencies in literature concerning the concepts of HEIs and International Management (IM) were gauged to realize the extent to which they may contribute to alternative perceptions in global Higher Education in Brazil. The theoretical framework was based on the articulation of such concepts, and data were connected to the interviews held with highly skilled scholars of three different public Brazilian HEIs using the methodology of oral histories. Data pointed traits and suggestions toward expanding internationalization in Brazilian HEIs, among which fostering international researchers and resource allocation systems for international research funding.

Keywords: Brazil. Higher Education Institution. International Management. Internationalization.

\section{Introduction}

This study aims to contribute to Brazilian Higher Education Institutions (HEIs) within an international perspective where globalization is an existence shaped by an increasingly integrated world economy, new information and communications

\footnotetext{
a Ministério da Defesa, Distrito Federal, DF, Brasil.

b Universidade Federal do Rio de Janeiro, Rio de Janeiro, RJ, Brasil.
} 
technology, the emergence of an international knowledge network, and other forces often beyond the control of HEIs (SOTULA, 2017).

Our main argument is that HEIs that value international research and international mobility of students and academics should contribute to enlarge the view of internationalization throughout Brazil, and push HEIs far beyond economic and political rationales considered by Knight and Wit (2018) to be key drivers for National policies, regarding internationalization of higher education.

To achieve this aim, we first introduce the most recent tendencies in literature concerning the concepts of HEIs and International Management (IM) that were articulated to produce the theoretical framework. Data collected were linked to the interviews held with scholars of three different public Brazilian HEIs using the methodology of oral histories (ALBERTI, 2013) to figure out how such scholars with extensive experience working in HEIs perceive the process of internationalization, and eventually presented possibilities to increase such dimensions in Brazilian HEIs.

The authors claim that HEIs should rather strengthen Brazilian research and value Brazilian academics, mainly those with global acknowledgement, and not solely focus on international student/academic mobility from an economic/ politic-oriented perspective that seems to prevail in literature today. It does not mean that fostering international mobility in such view is not an asset, however, the argument we defend is that there is an overestimated agreement toward it, whereas there should arguably be a balance with students/academics and their social/cultural motivations (KNIGHT; WIT, 2018).

We conclude raising awareness of equally increasing HEIs in an international outlook throughout Brazil.

\section{HEI vs IM: theoretical framework}

This section presents the main tendencies in literature concerning HEIs $v s$ IM. It aims to discuss their guiding concepts to contribute to the development of Brazilian HEIs internationalization toward a more balanced and democratic perspective among Brazilian regions. Therefore, this work focuses on the internationalization in the institutional level, although the national level has an important influence on the international dimension of Higher Education through policy, funding, programs, and regulatory frameworks. "Yet it is usually at the individual, institutional level that the real process of internationalization is taking place" (KNIGHT, 2004, p. 6). 
The study of Martignago, Alperstedt and Cário (2013) on the field of IM pointed that although IM is not restricted to organizations, but supports other types such as universities (MIURA, 2009), IM of HEIs was not present, but themes related to HEIs commercialization processes were the most frequent and corresponded to almost half of the studies (SAMPAIO; SAES, 2014). It is probably due to the lack of Brazilian organization strong tradition on internationalization so far, with few exceptions (ROCHA, 2003).

Literature concerning IM seems to focus more on internationalization processes, foreign trade, expatriated business executive, merges and acquisitions (MARTIGNAGO; ALPERSTEDT; CÁRIO, 2013). Also, it informs there was a tendency to consider culture in the period of 2001-2006 that completely disappeared in 2008. Indeed, Knight (2004) affirmed "there has been a definite shift from alliances for cultural purposes to economic purposes" (p. 23). It seems to be one of the reasons why HEIs have valued international partnerships for commercial purposes, instead of rating an international/intercultural approach within the campus, research, and service functions (ALTBACH; REISBERG, 2018).

Data we extracted from the bibliographic research seems to pinpoint that in Brazil the focus on HEIs $v s$ IM is still modest. It reinforces our argument about the relevance of enlarging the discussion and approaching possible challenges and views toward improving HEIs' internationalization management throughout Brazil.

There is seemingly a consensus that Brazil is not as active as other emerging economies, particularly the more aggressive Asian "tigers," when it comes to expanding the provision of higher education, and its scientific and technological infrastructure. Considering the political and economic imperatives undergirding such investments across the globe, the state of affairs in Brazil seems to be one of relative complacency (SALMI, 2009).

In this regard, Stallivieri (2002) stressed the relevance of the interface between IM vs HEIs and pointed "[...] factors that compromise the success in the realization of good cooperation programs, whether bilaterally assumed or funded by government agencies" (p. 5).

Activities that are not so successful due to some obstacles that may slow down the internationalization process, such as: lack of awareness of the academic community, passive attitudes on the part 
of the institution's faculty and students, lack of clear strategies for internationalization, lack of cultural recognition, unavailability or unfeasibility of adaptation of foreign communities, language barriers or high geo-educational distance, among others $[\ldots]$ (our marks).

As far as bidirectionality is inherent in HEIs internationalization Sutton, Eggington and Favela (2012) argued, their benefits claim for a more collaborative approach. As the authors stated, it is a process of moving out into the world and a process of joining broader alliances, thus it is clear that international knowledge is better built through international dialogue. Nonetheless, we have noticed that this perspective and/or awareness should be first constructed within national borders to move out into the world as stated by Sutton, Eggington and Favela (2012).

In the case of Brazilian HEIs, the present study seems to unveil those institutions still lack such an integrative approach within borders to operate/develop bidirectional and boundary-bending forces that "[...] are varied and even sometimes conflicting" (p. 148) as argued by Sutton, Eggington and Favela (2012) . Truly, internationalization has built new HEI designs that have led them become broader and homogeneus (LIMA; MARANHÃO, 2011), thus we claim such needs should be guided by what critical internationalization scholars, such as Shahjahan (2016) and Stein (2019), have already argued: re-imagining decolonial possibilities within global Higher Education is a necessary next step for the field, and in this regard, Knight (2004) pointed that although it was challenging for developing such a definition, internationalization was being widely used to discuss HE international dimension and, more broadly, post-secondary education.

As reported by Sampaio and Saes (2014) the theme of Higher Education has been frequent in the literature of the area, mainly in the northern hemisphere, although the link between HEIs and internationalization of Education has been around for some time. Concerning this subject, Knight (2003) pointed the definition of internationalization in the Education sector has only soared since the early 1980s, and that in the 1990s the discussion on using the term international Education centered on differentiating it from comparative, global and multicultural education. However, Sampaio and Saes (2014) affirmed that although recent, the phenomenon of internationalization is already the object of many studies undertaken in numerous parts of the globe. The analyses about it, paradoxically, also exposes the singularity of the new phenomenon in each country, and even in each region, thus "[...] la internacionalización no ocurre de la misma manera en todos los países y ni siquiera en todas las instituciones de Educación Superior" (SOUZA; DE FUKUOOI; SANZ CASADO, 2020, p. 799). 
Knight (2003) has proposed the following definition for internationalization in higher education: "Internationalization at the national, sector, and institutional levels is defined as the process of integrating an international, intercultural, or global dimension into the purpose, functions or delivery of postsecondary education" (p. 2).

Concerning that, Brandenburg and Wit (2015) argued that the concept of Higher Education internationalization and its development coincided with the rivaling term globalization. Thus, to the author, whereas the term internationalization has gained moral weight of justice and equity that needs to be defended today, globalization is loaded with negative connotations of a world of pure economic benefits allegedly represented by the term.

Knight (2003) had agreed that "in fact, substantial efforts have been made during this past decade to maintain the focus on the internationalization of Education and to avoid using the term globalization of education" (p. 3). Globalization is a key reality in the 21 st century, thus it has already deeply impacted and changed Higher Education from a local to a global reality (ZHU, 2015).

To Hawawini (2016), the standard and widely cited definition of Higher Education internationalization is defined by Knight (2003). Nevertheless, the European Parliament (WIT; HUNTER, 2015) revised Knight's (2003) commonly accepted working definition for internationalization as "the intentional process of integrating an international, intercultural or global dimension into the purpose, functions and delivery of post-secondary education, in order to enhance the quality of Education and research for all students and staff, and to make a meaningful contribution to society" (p. 4).

In this regard, Richardson et al. (2019) claimed that the integration of world economy, information and communications technology has built an intersection through which Higher Education leaders have to go through since building capacity for global institutions is a need for HEIs today. As a result, it demands the use of all internal resources to improve their quality (MEANS, 2017).

As stated in Knight $(2004,2012)$ organizational strategies (governance, operations, services, and human resources) are relevant as they aim to give sustainability to the internationalization process, however, Miura (2009) argued that despite HEIs efforts and awareness on the importance of internationalization, conditions/ strategies at the organizational level for the support to such process are still not perceived. Miura (2009) also mentioned a point that strongly weakens the 
HEIs internationalization process, and it lies in strategies related to operations which include integration of planning, budget, and quality review systems at the institutional and departmental level; appropriate organizational structures such as: liaison and coordination; balance between centralized and decentralized promotion $v s$ internationalization management; adequate financial support and resource allocation systems. It is worth mentioning these points were openly cited in the oral histories we have held here.

Discussions raised concerning HEI $v s$ IM do not intend to cover the whole subject, but to underline the main tendencies in literature which seem to suggest there has been more commercial approach to internationalization by traditional public and private institutions. This is confirmed by the World Trade Report (WORLD TRADE ORGANIZATION, 2019) where Education appears among the 15 service sectors, thus has become a potentially lucrative trade area what is in opposition to 1998 Unesco Conference in Paris that sought to preserve Higher Education cultural and humanistic singularities. In this direction, Sampaio and Saes (2014) affirmed the internationalization of Higher Education is closer not only to commercial interests, but also to strategies to attend foreign policies and National priorities. This was also stressed by Knight and Wit (2018) who pointed to commercialization as a key driver for National policies in Higher Education internationalization, however, the value and need for quality are constantly expanding, thus claiming for the assurance of quality as a top concern for global HEIs (WILKINS; JUUSOLA, 2018).

To Qureshi et al. (2014) internationalization has emerged as one of the defining issues of higher education, and different perceptions came out to explain HEIs internationalization process based on their structures and strategic plans. However, there are still challenges to identify the basic steps through which Higher Education may move into internationalization. The authors identified the basic dimensions for the improvements of services and structure that lead to Higher Education internationalization, and proposed the use of define, measure, analysis, improve and control cycle for HEIs continuous improvements.

According to Roga, Lapina and Müürsepp (2015) internationalization is becoming one of the main priorities of HEIs not only in Europe, but also worldwide. Most HEIs include internationalization as a part of their strategies, thus contributing to the development of study programs in English, guest lecturer involvement and participation in other activities aimed at attracting foreign staff and students who are an asset to HEIs where they are studying.

Sá and Grieco (2015) examined the approach Brazil took to bolster internationalization of Higher Education between 2005-2015. They identified 
three key areas: human resources development; institution building; and international partnerships. Their analyses of initiatives in these areas demonstrated that Brazil does not follow global trends, such as the creation of world-class HEIs, or the pursuit of "excellence initiatives" to help such institutions reach higher positions in global rankings. Instead, recent strategies for international collaboration in Higher Education follow a variety of domestic goals that encompass the logics of foreign policy and the internal priorities of federal research agencies such as the National Council for Scientific and Technological Development $(\mathrm{CNPq})$ and the Coordination for the Improvement of Higher Education Personnel (Capes), and Education agencies. Given that Higher Education regulation is highly centralized under federal government (PEREIRA LAUS; COSTA MOROSINI, 2005), to understand its policy is critical to grasp efforts at internationalization in Brazil.

In this direction, Knight and Wit (2018) have recently stated that economic and political rationales are mainly driving forces for National policies concerning the internationalization of higher education.

Concerning the knowledge production on the subject, Sampaio and Saes (2014) pointed to the regional distribution of studies on Higher Education internationalization, chiefly those in the form of articles. The authors mentioned they had noted such studies are concentrated in international journals, and originate from the Southeastern, Center-West and Southern regions of the country.

Our study seems to point out there should be a more balanced approach toward internationalization throughout Brazilian HEIs whose rankings have been suggesting that in the South and Southeast of Brazil internationalization is more robust compared to other regions (FOLHA DE SÃO PAULO, 2019). According to such author, the best HEIs are in the South and Southeastern regions. Moreover, extant scholarship suggests that given the rise of global comparison indicators and rankings as well as the world-class university concept, "no longer are countries comfortable with developing their Higher Education systems to serve their local or national communities" (LIN, 2009).

In this context, our contribution seeks to shed light toward a balanced approach on the internationalization of HEIs in Brazil that supports researchers' diverse experiences and expertise, as well as differences in research rationales since we believe such a perspective should enhance the international dimension of research and knowledge as well as value academics/researchers thoroughly Brazilian regions. 


\section{Study design}

The methodology comprises oral histories that were collected from three scholars (hereafter interviewee 1, 2 and 3) of three different public Brazilian HEIs. It is important to note that due to research ethical sensitivities interviewees' identities and HEIs locations have been kept anonymous.

To Alberti (2013) oral histories are characterized by the testimonies of those actors who had lent experiences witnessed of a specific subject of research interest, and thus contribute to a better understanding of a field of study that most of the times are ignored by specialists and the public in general. These data are collected through rigorous and scientific proved status and registered over ethnical and methodological procedures (ALBERTI, 2013).

\subsection{Perceptions of internationalization by HEls managers/scholars}

Interviewees in their oral histories showed different perceptions on the subject, although data collected from their narratives indicated perspectives that concern a better HEIs internationalization through a more focused management that seeks to promote equality/equity between Brazilian regions, and mainly the welfare of society.

The interviewees have more than once shed light on HEIs management of financial aspects. For example, to raise funds for research, the interviewees recommended to strengthen partnerships between HEIs and organizations to launch financial support for research. In this regard, according to them, such institutions must point out the relevance of their research to business and industrial world. Consequently, they contend global research results would also be promoted since there would likely be a multinational dealing with the data presented.

Knight (2004, p. 24-25) had claimed that "international development work based on mutual benefits for all partners continues to be a key aspect of postsecondary internationalization. Knight (2003) mentioned that this includes delivery by traditional HEIs, but also by new providers such as multinational companies that are often more interested in the global delivery of their programs and services than the international or intercultural dimension of a campus or research and service functions.

Another aspect mentioned by the scholars interviewed concerns the research funding agencies in Brazil such as $\mathrm{CNPq}$ and Capes. The interviewees strongly recommended to foster these agencies to have more funding available for research 
projects, so as researchers will be able to engage into foreign research activities more actively, such as participation in worldwide congresses, conferences, and project partnerships development with academic institutions in Brazil and/or abroad as well.

The financial aspects pointed out by the interviewees have been so far strictly related to HEIs management that must be addressed; otherwise, they argue that it will not be possible for these institutions to face financial challenges, adequate research funding, and resource allocation systems. It is worth mentioning that these aspects rely on a reasonable budget expected by appropriate academic policies as expressed at the institutional-level program and organization strategies listed by Knight $(2004,2012)$. Today, HEIs are facing budget pressure chiefly due to the challenges imposed to provide new services to embrace diversity (ALTBACH; REISBERG; RUMBLEY, 2019).

When asked how Brazilian HEIs in different regions have responded to the role of academics in HEIs global perspective (mainly public HEIs in North Brazil that according to the rankings are in disadvantage compared to resources available in the South/Southeast ones), interviewee 2 mentioned that "it is necessary to develop the North region. Those who have the money are the ones who hold the power of decision." He also added that "it depends on what they [any organization interested in developing a research project in the North region] want from here [the North]. There should be a project and a return should be presented as well." (Interview held on Oct $31^{\text {st }}, 2019$ ).

Once more interviewee 2 emphasized that HEIs internationalization depends on those who hold the power of decision, and so pointed out the management role of the top Higher Education managers today. Slaughter and Leslie (1999) had already mentioned top managers and academic leaders' ability to govern HEIs on the grounds of student competition, academic capitalism, and the tyranny of international rankings since such factors make them an entity torn between the specificities of Higher Education organizations and their growing entrepreneurship. In fact, Guri-Rosenblit (2010) stated that global HEIs have moved from traditional means for preparing future workers and improving preparation to include innovation and entrepreneurship. Also, Christensen, Gornitzka and Ramirez (2019) and Goldin and Katz (2018) affirmed that HEIs are becoming business-like entrepreneurs by marketing themselves, building collaborative alliances, and preparing for newer, and emerging disruptive events.

Following interviewee 2, interviewee 3 talks about Brazilian biodiversity in North Brazil: "[...] the arrival of academics is almost always welcome. Of course, there 
are interests when we talk about Amazonia, for instance. There is an enormous greed for Amazonia's biodiversity, and thus there is a concern of Brazil to protect this biodiversity and assure Brazil keep the knowledge to benefit" (Interview held on Oct $08^{\text {th }}$, 2019).

As noticed, interviewee 2 had shed light on management and on the task of HEIs high echelon managers to respond to the role of academics in a HEI international perspective, and in this regard, interviewee 3 reminded that " $[\ldots]$ somehow, there is a portion of management that thinks the act of signing an agreement means internationalization. It is not like this" (Interview held on Oct 08 ${ }^{\text {th }}, 2019$ ).

Interviewee 3 called attention to the relevance of a real HEIs management in an international perception. "[Top manager] may have one very well-prepared group, and support it, but it is not a need to have the whole HEI raising the internationalization flag" (Interview held on Oct $08^{\text {th }}, 2019$ ). To contextualize that subject, the referred scholar mentioned an international mission $\mathrm{s} /$ he took part. On that occasion, a Brazilian high echelon manager was proud of having signed more than a hundred of cooperation agreements. "[...] an idle measurement, to think that an agreement will generate some benefit. An agreement itself stays into the drawer and does not produce anything. It is only a justification for him/her to travel [abroad]" (Interview held on Oct $08^{\text {th }}, 2019$ ).

Because the relevance of projects and appropriate academic policies have been highlighted by the interviewees, they seem to convey the idea that there should be the achievement of more equitable distribution of resources in Brazilian HEIs through an emphasis on HEIs management in an international perspective. In fact, when we asked interviewee 2 what factors could favor HEIs internationalization, it was reaffirmed that the focus should be on management since it relies on the top manager, thus it is a question of HEI management.

When asked to participate in the oral history, interviewee 1 answered: "I am a bit forgetful. I do not want to be involved in this research". Interviewee 1's refusal to offer an oral history informed that management seems to be a real fragile issue amongst HEIs administrators, who seem not to be comfortable to address the subject. The reason why such interviewee did not feel comfortable to offer an oral history may be based on the assertion of Bianchetti and Magalhães (2015) who highlighted that high echelon administrators "[...] now assigned management roles that redefine their identity as academicians." (BIANCHETTI; MAGLHÃES, 2015, p. 17, free translation), chiefly because the governance of HEIs seems to be under constant supervision and evaluation of the state as Musselin (2009) had pinpointed. 
We consider interviewee 1's attitude may perhaps be hiding other factors that are probably inhibiting the administrators to take part in the present study. Those factors might as well be probably inhibiting the necessary actions to promote internationalization that should be motivated and developed by the administrators of HEIs themselves. Although we do agree it is a complex and sensitive subject, we claim it must be faced and challenged by the HEIs' administrators to promote effective actions to diminish the unfair distribution of resources for research throughout Brazilian regions.

In fact, when asked to what extent HEI internationalization could impact the development of Brazil, interviewee 2 stated that "it depends on administrators' desire [financially speaking], on where they put the money. [For example], what do they want [...], donation or research projects? [...]." (Interview held on Oct $31^{\text {st }}$, 2019). Once more, the role of HEIs' administrators was highlighted.

Interviewee 2 also called attention to more internal management factors, such as the appreciation of international researchers, whether they have scholarship or not; their global network; the possibility of inviting them to present their work and to develop lectures; as well as to prepare students to go abroad and present their works.

Some aspects pointed out by the interviewees can be considered as more subjective and multicultural factors that we consider relevant, such as a compliment and/or a stronger incentive for researchers, whether they already have funding or not, since they keep on bringing a worldwide status for HEIs. These are factors that rely on a multicultural management perspective already emphasized by authors such as Canen and Canen (2005), and Guimarães, Tadeucci and Oliveira (2013) who value differences and plurality within HEIs, as well as researchers that already develop international research.

We claim an articulation of all interviewee's perceptions should be the ideal since only the financial support does not guarantee the appreciation of research, and at the same time only the appreciation of research is not possible if funding is scarce. In this regard, the second interviewee's recommendation seems to be relevant in that he claims that internationalization depends mostly on HEIs management, and not on financial aspects. He posits that such aspect relies on a multicultural HEIs management attitude of valuing diversity, different research perspectives and paradigms, valuing the enrichment of diverse opinions (GUIMARÃES; TADEUCCI; OLIVEIRA, 2013). When asked to what extent HEIs value Brazilian scholars with international transit and/or foreign researchers, interviewee 2 said 
that such factor "is important, [because] it places HEIs into foreign visibility. Whether it is our interest or not. HEIs reach better rankings, and students will have better opportunities." (Interview held on Oct $31^{\text {st }}, 2019$ ).

Regarding HEIs mission/role, interviewee 2's perspective is "to form people to develop the state, and it is valid for private HEIs as well" (interview held on Oct $31^{\text {st }}$,2019). Moreover, the referred interviewee added that the role of academics is "to contribute to form the local teaching staff." (Interview held on Oct 31 st, 2019). Concerning the subject, interviewee 3 presented a broader perception on HEIs main role that is

to form competent and capable people, to form citizens aware of their responsibilities, and to contribute to society through relevant research that may bolster the nation economic development and the social improvement of its communities, cities and countryside, so it is a comprehensive function and a major responsibility (Interview held on Oct $08^{\text {th }}, 2019$ ).

Such interviewee also reminded that until the 50's "[...] Brazil was still in the pre-historic era of its HEIs consolidation [...]." He also added that there were great isolated researchers who developed their laboratories, although there was an unfavorable environment for those activities [research ones]. (Interview held on Oct $08^{\text {th }}, 2019$ ).

Brazil has always aimed the international model to consolidate its universities, but also innovated with the creation of $\mathrm{CNPq}$ and CAPES in 1951 [...] and there was already a component of internationalization at that time because it allowed to send researchers, young professors, or not professors yet, but young, to pursue master and then doctorate programs abroad. It was a very incipient activity. There was neither incentive nor national or local planning for this activity (Interview held on Oct $08^{\text {th }}, 2019$ ).

Interviewee 3 evidenced one aspect that concerns the current internationalization boom in Brazil. "Internationalization is overrated. Every HEI thinks internationalization is the way, but I do not see this way [...] Partially, this is due to the Brazilian environment tendency to make everything equal $[\ldots]$ " (Interview held on Oct $08^{\text {th }}, 2019$ ), referring to Brazilian HEIs' desire to produce research different from USA HEIs. "How much research HEIs are there in the US? Maybe one or two hundreds. How many college graduates? Thousands or 
more. For this interviewee, in recent years, intercontinental status turned to be a paradigm in Brazil since all universities want to internationalize without proper conditions, and this leads to an asymmetry comparing to worldwide HEIs. The number of projects with foreign HEIs signed by top managers was pinpointed by the referred interviewee.

$[\ldots]$ agreements that do not work $[\ldots]$ although there were various that stood out, [...] [such as] an internationalization benchmarked [built by a Brazilian HEI] since it has foreign visiting scholars, international students, [HEIs] promote events with the participation of foreign students who come to present their research developed in a doctorate program. [...] (Interview held on Oct 08 $\left.{ }^{\text {th }}, 2019\right)$.

Interviewee 3 mentioned an interesting experience about a HEI evaluation process when "[...] one of [the various commissions] was on internationalization [...] what they understood by internationalization, and what they were doing about it [...] the great majority of the units in the HEI had no parameter to measure internationalization" (Interview held on Oct $08^{\text {th }}, 2019$ ).

Interviewee 3 also highlighted that if we check the Times Higher Education World University Rankings (2019), it will be noted that HEIs neither measure signed agreements, nor capacity to send scholars abroad. As opposed to that, they only measure the capacity to attract researchers and post doctorate, undergraduate and graduate students. For such interviewee "this is the real internationalization" (Interview held on Oct $08^{\text {th }}, 2019$ ). The referred interviewee more than once pointed to the importance of the concept of internationalization and its consequence as mentioned before.

Apart from the critics concerning HEIs management in an international perspective, such interviewee mentioned its importance for the development of Brazil since the $19^{\text {th }}$ Century during Imperial times yet. The interviewee claimed many Brazilian HEIs were built with foreign countries support. "Those were a kind of a cooperation that came and did not necessarily take back information. It was not a search, but a naïve cooperation. [...] It was in 1874 [...]" (Interview held on Oct $08^{\text {th }}, 2019$ ).

Interviewee 3 emphasized that later, in the twenties, Brazil also had other positive experiences of naïve HEIs internationalization, such as an exchange that occurred between USA and Brazilian HEIs to provide Brazilian personnel's capacitation in the agriculture field. The interviewee reminded that in 1942 a Brazilian HEI was organized with the support of USA government that contributed with outstanding 
personnel, such as Brazilian professors who were just returning from the USA with master's and doctorate's degree. Such interviewee also called attention to other examples of internationalization within Brazilian HEIs that were worth mentioning, such as University B and its agreement with a European HEI that supported research groups, mainly in the mechanical engineering program. Also, University $\mathrm{C}$ had a strong cooperation with another European HEI with the coming of some prestigious philosophers. For this interviewee, these and other naïve cases had strongly helped Brazil in its capacitation, as well as other examples evidenced that stressed the relevance of HEIs management in an international view whose focus should be on the commitment to one of the missions of HEIs that is develop research geared towards promoting the development of the country over financing academic mobility chiefly geared to measure agreements signed and their capacity to send scholars abroad, whereas the capacity to attract academic mobility is the one that should be considered.

It is possible to infer by the narratives in the oral histories that Brazilian HEIs internationalization management has been focusing on the accomplishment of diverse global agreements signatures between HEIs, and on financial aspects needed to support faculty and foreign graduate students' mobility. We consider these perceptions should be (re)thought toward more concrete benefits for the Brazilian HEIs internationalization.

Table 1 - A summary of main themes of the study

\begin{tabular}{ll}
\hline Data & \multicolumn{1}{c}{ Results/Conclusion } \\
\hline & - International rankings and status create priorities for Brazilian \\
& HEls and are in tension with an equity-oriented approach to \\
& education. \\
Literature Review/ & To develop an international perspective, a more collaborative \\
Argument & approach among HEls is needed. \\
- It would be relevant to foster international researchers. & \\
- & HEls internationalization management focus on market economy \\
& and trade liberalization. \\
- It is important to strengthen partnerships between HEls and & organizations to launch financial support for research. \\
- It is relevant to foster research agencies to have more funding & available for research projects and to researchers. \\
Themes & HEls internationalization depends mainly on power of decision of \\
& the HEls managers. \\
- Challenges exist related to different meanings and criteria to & define and evaluate internationalization.
\end{tabular}

Source: The authors (2021) 


\section{Final thoughts}

The study suggests that in the context of globalization, where international Higher Education has become a crowded global marketplace, efforts should be made to integrate HEIs instead of prioritizing ones at the expenses of others. Still, there are challenges HEIs must face to equalize internationalization throughout Brazilian regions, and to press such institutions far beyond political, economic, and commercial interests.

Literature pointed that HEIs' policies affect or are affected by the international dimension of Education in both national and institutional levels. Still, 'world standards' have established hierarchies between different public HEIs and have determined the extent of funding and resources granted to these institutions. Thus, it has led to inequalities between different public institutions with a few considered as elite public institutions, while others are deemed of poor quality and low status. Brazilian HEIs management has been facing such international demands, which are directly reflected within national boundaries, leading to inequalities of resources, funding, and prestige of scholars. As a result, the pursuit of international rankings and status may create priorities for Brazilian HEIs and be in tension with an equity-oriented approach to education, as we have been observing in Brazilian regions where the South and Southeast HEIs have gained more prominence than the North.

Interviewees' perceptions in the oral histories indicated the need of HEIs to face financial challenges to balance and adequate research funding thoroughly Brazil, and resource allocation systems to mitigate the inequality of Brazilian regions. partnerships between HEIs and business/industrial world may contribute to raise funding for research. Also, a more prominent support of Brazilian agencies such as $\mathrm{CNPq}$ and Capes are strongly recommended by the interviewees to foster research projects and value a more active engagement into international research activities. Thus, HEIs, researchers, scholars and undergraduates would contribute to enlarge the view of internationalization throughout Brazil, and mainly contribute to the country's/society's development that would equally benefit from their findings.

Our argument stresses that HEIs should focus on management that move far beyond market economy and trade liberalization to value an even HEIs internationalization as part of the country's nation-building agenda to bolster links between HEIs and country's development.

We have noticed literature on the interface between HEIs $v s$ IM is still modest in Brazil. We suggest future do researches to deep the subject, looking forward to 
a more balanced distribution of resources and funding for research for Brazilian HEIs as well as HE stakeholders, chiefly to diminish brain drain in Brazil, and trigger/motivate highly skilled Brazilian scholars whose expertise must gain prominence to enhance the campus research and services. It is worth underlining the role of international researchers' network to HEIs internationalization to discuss their studies, chiefly now when Covid 19 has been challenging all of us.

As a result, we argue future studies could develop the subject, looking forward to point to challenges HEIs throughout Brazil must face to embrace postcolonial perspectives that claim for inclusion and collaboration from all academic sectors thoroughly. 


\section{Internacionalização das Instituições de Ensino Superior (IES): percepções de acadêmicos}

\section{Resumo}

Esse estudo busca contribuir com as Instituições de Educação Superior (IES) brasileiras em perspectiva internacional. Nosso argumento é que quando as IES valorizam a pesquisa internacional e a mobilidade acadêmica, contribuem para ampliar a visão da internacionalização em todo o Brasil e promovem essas instituições para além dos processos políticos, econômicos e de comercialização, considerados, hoje, os principais motores de mudança na internacionalização do Ensino Superior. Para tal, tendências mais recentes na literatura sobre os conceitos das IES e da gestão internacional foram avaliadas para verificar a extensão em que podem contribuir com percepções alternativas da internacionalização da Educação Superior no Brasil. O referencial teórico teve como base a articulação de tais conceitos e os dados foram articulados às entrevistas realizadas com acadêmicos altamente qualificados de três diferentes IES públicas brasileiras, por meio da metodologia de histórias orais. Os dados indicaram caminhos e sugestões para expandir a internacionalização das IES brasileiras, entre eles, ofomento de pesquisadores internacionais e de sistemas de alocação de recursos para o financiamento de pesquisas Palavras-chave: Brasil. Instituição de Educação Superior. Gestão internacional. Internacionalização.

\section{Internacionalización de las Instituciones de Educación Superior: percepciones de los académicos}

\section{Resumen}

Este estudio tiene como objetivo contribuir a las Instituciones de Educación Superior (IES) brasileñas dentro de una perspectiva internacional. Nuestro principal argumento es que cuando las IES valoran la investigación internacional y la movilidad internacional de estudiantes/académicos, dichas instituciones contribuyen a ampliar la visión de la internacionalización en todo Brasil y empujan a las IES más allá de los procesos políticos, económicos y de comercialización considerados, hoy en día, impulsores clave de la internacionalización. La Educación Superior cambia en términos de internacionalización. Para lograr este objetivo, se evaluaron las tendencias más recientes en la literatura sobre los conceptos de IES y Gestión Internacional para darse cuenta de hasta qué punto pueden contribuir a las percepciones alternativas en la Educación Superior global en Brasil. El marco teórico se basó en la articulación de dichos conceptos, y los datos se conectaron a las entrevistas realizadas con académicos altamente calificados de tres IES públicas brasileñas diferentes utilizando la metodología de historias orales. Los datos señalaron rasgos y sugerencias hacia la expansión de la internacionalización en las IES brasileñas, entre las que se encuentran el fomento de investigadores internacionales y sistemas de asignación de recursos para el financiamiento de la investigación internacional.

Palabras clave: Brasil. Institución de Educación Superior. Gestión internacional. Internacionalización. 


\section{References}

ALBERTI, V. Manual de história oral. 3. ed. Rio de Janeiro: FGV, 2013.

ALTBACH, P. G.; REISBERG, L. Global trends and future uncertainties. Change: The Magazine of Higher Learning, [s. 1.], v. 50, n. 3-4, p. 63-67, 2018 .

ALTBACH, P. G.; REISBERG, L.; RUMBLEY, L. I. Trends in global higher education: tracking an academic revolution. Leiden: Brill, 2019.

BIANCHETTI, L.; MAGALHÃES, A. M. Declaração de Bolonha e internacionalização da educação superior: protagonismo dos reitores e autonomia universitária em questão. Avaliação, Campinas, v. 20, n. 1, p. 225-249, mar. 2015. https://doi.org/10.590/S1414-40772015000100013

BRANDENBURG, U.; WIT, H. The end of internationalization. International Higher Education, [s. 1.], n. 62, p. 15-17, winter 2015. https://doi.org/10.6017/ihe.2011.62.8533

CANEN, A. G.; CANEN, A. Organizações multiculturais: logística na corporação globalizada. Rio de Janeiro: Ciência Moderna, 2005.

CHRISTENSEN, T.; GORNITZKA, A.; RAMIREZ, F. O. Reputation management, social embeddedness, and rationalization of universities. In: CHRISTENSEN, T.; GORNITZKA, A.; RAMIREZ, F. (eds.) Universities as agencies. Zurique: Palgrave Macmillan, 2019. p. 3-39.

FOLHA DE SÃO PAULO. Ranking universitário da folha de São Paulo (RUF). 2019. Disponível em: http://ruf.folha.uol.com.br/2019/. Acesso em: 11 jun. 2021.

GOLDIN, C.; KATZ, L. F. The race between education and technology. In: GRUSKY, D. B.; HILL, J. (eds.). Inequality in the 21st Century. New York: Routledge, 2018. p. 49-54.

GUIMARÃES, S. R. E. F.; TADEUCCI, M. S.; OLIVEIRA, A. L. Estudo bibliométrico em gestão intercultural, internacionalização e mobilidade acadêmica: foco no ensino superior. Janus, Lorena, v. 10, n. 17, p. 55-65, 2013.

GURI-ROSENBLIT, S. Digital technologies in higher education: sweeping expectations and actual effects. New York: Nova Science, 2010. 
HAWAWINI, G. The internationalization of higher education and business schools: a critical review. Singapore: Springer Singapore, 2016.

KNIGHT, J. Concepts, rationales, and interpretive frameworks in the internationalization of higher education. In: DEARDORFF, D. K, et al. (eds.). The SAGE handbook of international higher education. London: Sage, 2012. p. 27-42.

KNIGHT, J. Internationalization remodeled: definition, approaches, and rationales. Journal of Studies in International Education, [s. 1.], v. 8, n. 1, p. 5-31, Mar. 2004. https://doi.org/10.1177/1028315303260832

KNIGHT, J. Updated definition of internationalization. International Higher Education, n. 33, fall 2003. https://doi.org/10.6017/ihe.2003.33.7391

KNIGHT, J.; WIT, H. Internationalization of higher education: past and future. International Higher Education, [s. 1.], n. 95, p. 2-4, fall 2018. https://doi.org/10.6017/ihe.2018.95.10715

LIMA, M. C.; MARANHÃO, C. M. S. A. Políticas curriculares da internacionalização do ensino superior: multiculturalismo ou semiformação?. Ensaio: Avaliação e Políticas Públicas em Educação, Rio de Janeiro, v. 19, n. 72, p. 575-598, jul./set. 2011. https://doi.org/10.1590/S0104-40362011000400007

LIN, J. Foreword. In: SALMI, J. The challenge of establishing world-class universities. Washington, DC: The World Bank, 2009. p. ix-xi.

MARTIGNAGO, G.; ALPERSTEDT, G. D.; CÁRIO, S. A. F. Pesquisa em gestão internacional no Brasil entre 2001 e 2010: um estudo a partir dos anais do Enanpad. Revista Eletrônica de Estratégia \& Negócios, Florianópolis, v. 6, n. 2, p. 215-243, maio/ago. 2013. http://dx.doi. org/10.19177/reen.v6e22013215-243

MEANS, A. J. Education for a post-work future: automation, precarity, and stagnation. Journal Knowledge Cultures, [s. 1.], v. 5, n. 1, p. 21-40, 2017. https://doi.org/10.1007/978-981-13-6225-5_16

MIURA, I. K. O processo de internacionalização da Universidade de São Paulo: um estudo em três áreas de conhecimento. In: ENCONTRO DA ASSOCIAÇÃO NACIONAL DE PÓS-GRADUAÇÃO EM ADMINISTRAÇÃO, 33, 2009, São Paulo. Anais[...] São Paulo: EnANPAD, 2009. p. 1-16. 
MUSSELIN, C. The side effects of the Bologna Process on national institutional settings: the case of France. In: AMARAL, A. et al. European integration and the governance of higher education and research. London: Springer, 2009. p.181-205.

PEREIRA LAUS, S.; COSTA MOROSINI, M. Internationalization of higher education in Brazil. In: WIT, H. et al. (eds.). Higher education in Latin America: the international dimension. Washington, DC: World Bank, 2005. p. 111-147.

QURESHI, M. I. et al. Internationalization of higher education institutions: implementation of DMAIC cycle. Scientometrics, [s. 1.], v. 98, n. 3, p. 1-16, 2014. https://doi.org/10.1007/s11192-013-1163-9

RICHARDSON, M. D., et al. Building capacity for quality in global higher education. International Journal of Advanced Research and Publications, v. 3, n. 10, p. 28-34, Oct. 2019.

ROCHA, A. Por que as empresas brasileiras não se internacionalizam? In: ROCHA, A. (org.). As novas fronteiras: a multinacionalização das empresas brasileiras. Rio de Janeiro: Mauad, 2003.p. 13-28..

ROGA, R.; LAPINA, I.; MÜÜRSEPP, P. Internationalization of higher education: analysis of factors influencing foreign students' choice of higher education institution. Procedia - Social and Behavioral Sciences, [s. 1.], v. 213, p. 925-930, Dec. 2015. https://doi.org/10.1016/j.sbspro.2015.11.506

SÁ, C.; GRIECO, J. International collaboration in Brazilian higher education. Frontiers of Education in China, [s. 1.], v. 10, n. 1, p. 7-22, 2015. https://doi.org/10.1007/BF03397050

SALMI, J. The challenge of establishing world-class universities. Washington, DC: The World Bank, 2009.

SAMPAIO, H.; SAES, P. Internationalization of higher education: a balance of the literature in Brazil. In: AUPETI, S.; ESCOBAR, V. Internacionalizacion de la educacion superior y las ciencias en America Latina: um estado del arte. Caracas: Iesalc, 2014. p. 49-76.

SHAHJAHAN, R. A. International organizations (IOs), epistemic tools of influence, and the colonial geopolitics of knowledge production in higher education policy. Journal of Education Policy, [s. 1.], v. 31, n. 6, p. 694-710, 2016. http://doi.org/10.1080/02680939.2016.1206623 
SLAUGHTER, S.; LESLIE, L. L. Academic capitalism: politics, policies, and the entrepreneurial university. Baltimore: The Johns Hopkins University Press, 1999.

SOTULA, O. Contemporary trends in the sphere of higher education: a global level. Bulletin of the Cherkasy Bohdan Khmelnytsky National University. Economic Sciences, v. 1, n. 2, 2017. Era 2018

SOUZA, C. D.; DE FILIPPO, D.; SANZ CASADO, E. El papel de la internacionalización de la Educación Superior en la producción científica brasileña. Ensaio: Avaliação e Políticas Públicas em Educação, Rio de Janeiro, v. 28, n. 108, p. 784-810, jul./set. 2020. https://doi.org/10.1590/S0104-40362011000400007

STALLIVIERI, L. O processo de internacionalização nas instituições de ensino superior. Educação Brasileira: Revista do Conselho de Reitores das Universidades Brasileiras, Brasília, DF, v. 24, n. 48, p. 35-57, 2002.

STEIN, S. Beyond higher education as we know it: gesturing towards decolonial horizons of possibility. Stud Philos Educ, [s. 1.], v. 38, p.143-161, 2019. https://doi.org/10.1007/s11217-018-9622-7

SUTTON, S, B.; EGGINGTON, E.; FAVELA, R. Collaborating on the future: strategic partnerships and linkages. In: DEARDORFF, D. K, et al. (eds.). The SAGE handbook of international higher education. London: Sage, 2012. p. 147-166.

WILKINS, S.; JUUSOLA, K. The benefits \& drawbacks of transnational higher education: myths and realities. Australian Universities' Review, Melbourne, v. 60, n. 2, p. 68-76, 2018.

WIT, H.; HUNTER, F. Understanding internationalisation of higher education in the European context. In: EUROPEAN PARLIAMENT. Directorate-General for International Policies. Policy Department B: Structiraç amd Cohesion Policies. Internationalisation of higher education. Brussels, 2015. p. 41-58. Available from: https://op.europa.eu/en/publicationdetail/-/publication/1b743fec-8b6c-45c2-aa9e-2fdf0967757b/language-en. Access in: 14 ser. 2020.

WORLD TRADE ORGANIZATION. World trade report 2019: the future of services trade. Available from: https://www.wto.org/english/ res_e/booksp_e/executive_summary_world_trade_report19e.pdf. Access in: 11 jun. 2021. 
WORLD UNIVERSITY RANKINGS. World university rankings 2019. Available from: https://www.timeshighereducation.com/world-universityrankings/2019/world-ranking\#!/page/0/length/25/locations/BR/sort_by/rank/ sort_order/asc/cols/stats. Access in: 18 dez. 2019.

ZHU, C. Organizational culture and technology-enhanced innovation in higher education. Technology, Pedagogy and Education, v. 24, n. 1, p. 65-79, 2015. https://doi.org/10.1080/1475939X.2013.822414

\section{Information about the authors}

Rejane Pinto Costa: Retired Brazilian army officer and former member at Escola Superior de Guerra. Postdoc at Universidade Federal do Rio de Janeiro. Researcher at Multicultural Studies Group - Grupo de Estudos Multiculturais at Universidade Federal do Rio de Janeiro/Conselho Nacional de Desenvolvimento Científico e Tecnológico-CNPq. Contact: rejpcosta@gmail.com

iD http://orcid.org/0000-0002-3062-3538

Alberto Gabbay Canen: Postdoc at University of Strathclyde, Scotland. Retired Full Professor at Instituto Alberto Luiz Coimbra de Pós-Graduação e Pesquisa em EngenhariaCOPPE/Universidade Federal of Rio de Janeiro. President of the International Center for Innovation and Industrial Logistics. Contact: agcanen@gmail.com

(iD) http://orcid.org/0000-0002-1508-2868 